\title{
The Economist's Oath: A Review Essay
}

International Review of Applied Economics 29 (1), 2015: 125-8.

\section{Sheila Dow}

Prepared for the International Review of Applied Economics

\begin{abstract}
George DeMartino's 2011 monograph, The Economist's Oath: On the Need for and Content of Professional Economic Ethics, provides an excellent basis for the development of a discourse on the ethics of economists. This review focuses on the way in which mainstream economists' arguments against consideration of ethics follow from their presentation of economics as a purely technical subject, and the implication that this pretense itself is unethical. The complexity of ethical issues within a pluralist approach to economics is explored, ranging from the institutional environment within which economists practice to epistemological questions.
\end{abstract}

Key words: economics profession, ethics, epistemology

\author{
Division of Economics \\ Stirling Management School \\ University of Stirling \\ Stirling FK9 4LA \\ UK \\ Tel: +44-1786-822206 \\ Fax: +44-1786-467469 \\ e-mail: s.c.dow@stir.ac.uk \\ and \\ Department of Economics \\ University of Victoria \\ 3800 Finnerty Road \\ Victoria, BC V8P 5C2 \\ Canada
}

August 2014 
Issues of professional ethics have arisen in the public debate as to how far economists were responsible for the financial and economic crisis. Economists in public office, such as Alan Greenspan, have admitted mistakes, as have academic economists, such as Tim Besley in his letter with Peter Hennessy in response to the British Queen's query in 2009. But the mistakes have been framed as technical mistakes with no reference to ethics. And yet the real consequences of these 'mistakes' have been staggering, with widely differing distributional effects. Much harm has been done. Should economists take moral, as well as technical, responsibility and should they be encouraged to study and debate how that responsibility should be discharged, i.e. professional ethics? The purpose of George DeMartino's volume, The Economist's Oath, is to make a strong case for an affirmative answer to both questions and to map out how we might proceed.

The analysis is conducted carefully and in a measured way - a model of ethical advocacy. It is addressed to economists as researchers, teachers and in the various roles in the public and private sectors within which they provide guidance and advice. For a start the question is contentious as to whether or not economics is a profession. DeMartino argues that economics should be a profession in the sense of requiring pursuit of the public good and some form of self-governance. He establishes a broad canvas on which ethical issues arise. For DeMartino, ethics range 'over privileges, power, influence, responsibilities, challenges, institutional and epistemic milieu' (p. 14). He considers professional ethics primarily for well-intentioned economists, rather than the usual focus on generic ethical issues surrounding wilful wrongdoing (plagiarism, conflict of interest etc). Economists who aim to serve the public interest are faced with challenging ethical issues which arise from the complexity of professional practice. And yet there is no training or substantive professional discourse to guide them. 
In the first half of the volume DeMartino carefully knocks down the various arguments put forward against considering professional ethics for economists. (This is complicated by the common practice of conflating professional ethics with a code of conduct, which can be dismissed on grounds of enforcement difficulties.) Much of the argument is built on a detailed account, based on interviews, of the extent and nature of economists' involvement in a variety of roles which involve the application of theory to practical issues. 'Economists who have reflected on their work in government and other institutions emphasize that effectiveness requires economists to abandon the role of neutral technocrat and to arm themselves with an arsenal of rhetorical, political and other strategies. Economists in dense bureaucracies of competing interests and values must cultivate the ability to translate economics ideas into everyday language, build alliances, win votes, and marginalize opponents' (DeMartino 2011: 36). He reports the various pressures under which policy advice is given and which involve ethical judgements: tight deadlines, pressure to promote the interests of clients, communication requirements which distort what is being communicated, job market pressures, and so on.

The fact that academic economists can distance themselves from many of these particular ethical challenges may go some way to explaining the aloof stance of mainstream economists with respect to professional ethics. Indeed the authority deployed by academic economists above the fray of application is all the more insidious for suppressing discussion of ethical issues. DeMartino (2011: 116) summarises his case for professional ethics as follows: economists enjoy an 'intellectual monopoly over subject matter of tremendous social significance', they enjoy 'institutional power’, economic policy can cause unanticipated and uncompensated harm and economic knowledge is uncertain. 
The epistemological argument is fundamental. The core of the objections from mainstream economists comes from a positivist epistemology which presents economics as a technical subject. This approach has a series of consequences for how the idea of professional ethics is approached. First, it renders moot the relevance of considering application of theory since the ethical responsibility is seen to lie with the advisee, or with the economist in an additional capacity (such as Chairman of the Fed) rather than the economist qua economist. Second, theoretical conclusions are regarded as value free, the values (and thus ethical responsibility) to be introduced by the policy-maker. Third, the content of mainstream economics which follows from this epistemology is built on axioms with respect to rational optimising behaviour which belie considerations of institutions, power and the role of rhetorical persuasion. Economic behaviour is treated as lawlike, such that predictions of theory are subject to quantifiable risks, not to fundamental uncertainty. Paradoxically, rational self-interest encourages opportunistic behaviour and thus the need for sanctions on any resulting unethical behaviour (of the generic sort, e.g. resulting from conflict of interest) in the application of economic theory in the provision of advice, but then this would require the creation of a monopolistic licensing structure for economics. Finally this mainstream understanding of economists' behaviour, by distracting from any pursuit of the public good, erodes the notion of economics as a profession.

A non-positivist epistemology on the other hand supports the view that ethical issues arise as much within academic economic theorising as in its application. Any economic theorising involves values, such as disregarding equity in the pursuit of efficiency, or treating market-determined factor returns as just. Theory incorporates some specification of the 'public good'. These values carry forward to policy application. DeMartino takes particular issue with the 'maxi-max' decision rule which ranks policy options in terms of their best possible outcomes, regardless of all other 
possibilities. This rule had disastrous outcomes when applied to structural reform of developing and transitional countries. This example also illustrates the significance of treating predictions of policy outcomes as stochastic when they are in fact fundamentally uncertain.

Of course even a stochastic prediction allows for the possibility of harmful outcomes, and an equivalent of the medical ethic 'do no harm' could be applied. Indeed monetary policy has recently tended to apply a mini-max principle (avoiding worst-case outcomes). But if probabilities of outcomes are not known, not least because the range of possible outcomes is not known, then concern that no harm be done requires serious exploration. But the alternative of no policy action such that no harm is done is to go too far to the other extreme; the very existence of public institutions impacts on the private sector so 'no state involvement' is not an option. No action is clearly not an option for companies. Further, since any policy is likely to do some harm (often unanticipated) as well as some good, professional ethics come into play even more (DeMartino 2014).

Non-positivist economics arises from some form of open-system ontology which precludes the closed-system theorising of mainstream economics. The various non-mainstream schools of thought with open-system ontologies treat institutions, power and rhetoric as important factors explaining the dominance of mainstream economics, within academia but also outside academia. Indeed the presentation of policy advice in an authoritative manner as 'positive' and technical when in fact it is not in itself unethical. But institutions, power and rhetoric are also regarded as important aspects of the socio-economic system to be addressed by theory. Non-positivist economists are therefore well placed to contribute to a new discourse on professional ethics. Further, having discussed the crisis as the consequence of a monist mainstream approach to 
economics, DeMartino makes the case for pluralism, not only on epistemological grounds, but also on ethical grounds. A range of perspectives can build a more robust discourse on the consequences of policy advice and therefore of the harm as well as the good that it might do. But the first step towards such a discourse has to be mutual respect. The promotion of pluralism concludes the economist's oath which DeMartino offers at the end of the book.

Pluralism of course raises particular ethical issues which are the counterpoint to the issue raised by the mainstream pretence of scientific neutrality. The issue of professional ethics appears to be relatively simple for a positive science which simply offers up technical conclusions for input into value-laden policy discussion. But even then mainstream economists have balked at the idea of formally proscribing unethical behaviour, cutting across the rational optimising behaviour of economists. Non-mainstream economists too, including myself, are wary of formal codes of conduct because of the potential for them to be an additional, institutionalised mechanism by which mainstream economists could wield power over non-mainstream economists. In particular, the ethical requirement for a professional to display some minimal level of competence begs the question of what competence in economics consists of: prioritising expertise in formal mathematics or in historical understanding, for example. An oath is another matter, as a statement of intent with respect to ethics based on 'intellectual and pedagogical practices and traditions' (p.16). A code is a clear set of rules. But professional ethics for economists are anything but simple, and do not lend themselves to strict rules. Within a pluralist environment for example each school of thought has its own understanding of the subject matter and how to build knowledge about it. The onus is on the economist to explain and make the case for, not only particular policy advice, but also the perspective and framework which generated it. It is so much more simple, and yet unjustifiable, to assert one best approach which is beyond discussion. 
The main thrust of this book is that economists' professional ethics is a substantial and complex subject area which currently is not addressed either in academic research or in economics education. The material covered demonstrates the scope for professional ethics to be a distinct field in economics. DeMartino points out that discussion of professional ethics might lead to the establishment of a code of conduct, or not; the discussion needs to come first. The issue of professional ethics for economists is not new, but never before has there been such a thorough and thoughtful exposition on the topic. DeMartino is to be congratulated on leading a growing interest in the topic, building on his early work which predated the crisis, and, with Deirdre McCloskey, has edited a substantial Handbook, with thirty-eight entries on the subject, which will come out early in 2015.

\section{References}

DeMartino, G F (2011) The Economist's Oath: On the Need for and Content of Professional Economic Ethics. Oxford: Oxford University Press.

DeMartino, G F (2014) 'Econogenic harm, economists, and the tragedy of economics', http://blog.oup.com/2014/06/econogenic-harm-professional-economic-ethics/ accessed 25 August 2014.

DeMartino, G F and McCloskey, D N, eds (forthcoming 2015) OUP Handbook on Professional Economic Ethics. Oxford: Oxford University Press. 
